\title{
PHDs inhibitor DMOG promotes the vascularization process in the AV loop by HIF-1a up-regulation and the preliminary discussion on its kinetics in rat
}

Quan Yuan ${ }^{1,2+}$, Oliver Bleiziffer ${ }^{1 \dagger}$, Anja M Boos ${ }^{1+}$, Jiaming Sun ${ }^{2}$, Andreas Brandl $^{1}$, Justus P Beier ${ }^{1}$, Andreas Arkudas ${ }^{1}$, Marweh Schmitz ${ }^{1}$, Ulrich Kneser ${ }^{1,3}$ and Raymund E Horch ${ }^{1 *}$

\begin{abstract}
Background: The Arterovenous Loop (AV Loop) model is a vascularization model in tissue engineering research, which is capable of generating a three dimensional in vivo unit with cells as well as the supporting vessels within an isolation chmaber. In our previous studies the AV loop in the isolation chamber was discovered to undergo hypoxia, characterized by Hypoxia Inducible Factor (HIF) up-regulation. The vascularization followed the increase of HIF-a temporally, while it was spatially positively correlated with the HIF-a level, as well. This study aims to prove that HIF-1a up-regulation is the stimulus for vascularization in the AV loop model.

Method: The AV loop model in rats was created by interposing a femoral vein graft into the distal ends of the contralateral femoral artery and vein, and the loop was embeded in fibrin matrix and fixed in isolation chamber. PHD (prolyl hydroxylases) inhibitor DMOG (Dimethyloxallyl Glycine) was applied systemically in the rats in $40 \mathrm{mg} / \mathrm{KG}$ at day 0 and day 3 (DMOG-1), or in $15 \mathrm{mg} / \mathrm{KG}$ at day 8, day10 and day 12 (DMOG-2). Two weeks later the specimens were explanted and underwent morphological and molecular evaluations.

Results: Compared to the control group, in the DMOG-2 group the HIF-1a positive rate was siginicantly raised as shown in immunohistochemistry staining, accompanied with a smaller cross section area and greater vessel density, and a HIF-1a accumulation in the kidney. The mRNA of HIF-1a and its angiogenic target gene all increased in different extends. Ki67 IHC demostrate more positive cells. There were no significant change in the DMOG-1 group.

Conclusion: By applying DMOG systemically, HIF-1a was up-regulated at the protein level and at the mRNA level, acompanied with angiogenic target gene up-regulateion, and the vascularization was promoted correspondingly. DMOG given at lower dosage constantly after one week tends to have better effect than the group given at larger dosage in the early stage in this model, and promotes cell proliferation, as evidenced by Ki67 IHC. Thus, this study proves that HIF-1a up-regulation is the stimulus for vascularization in the AV loop model and that the process of the vessel outgrowth can be controlled in the AV Loop model utilizing this mechanism.
\end{abstract}

Keywords: Hypoxia, Vasculorization, Arteriovenous loop, PHD inhibitor, Dimethyloxallyl Glycine, Kinetics

\section{Background}

Tissue engineering is a very promising technology but until now has a limitation of obtaining large three dimensional constructs with a reliable vascularization that would resemble living tissue. In contrast to in vitro models, in in vivo tissue engineering studies, the cells planted into

\footnotetext{
* Correspondence: raymund.horch@uk-erlangen.de

${ }^{\dagger}$ Equal contributors

'Department of Plastic and Hand Surgery, University Hospital of Erlangen,

Friedrich Alexander University, Erlangen Nuernberg, (FAU), Germany

Full list of author information is available at the end of the article
}

the three-dimensional construct require a sufficient perfusion from local blood capillary network [1]. As the basic units that built up the organism, in most cases, the cells draw their nutrition from the diffused molecules from the blood capillaries that are no more than $200 \mu \mathrm{m}$ away [2,3]. Thus, the key to successful tissue construction is to vascularize the constructs quickly and efficiently.

The Arteriovenous Loop (AV Loop) model first described in 1979 [4] is an in vivo vascularization model for surgical purposes. It is composed by interposing a

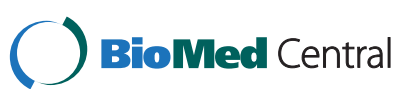

(c) 2014 Quan et al.; licensee BioMed Central. This is an Open Access article distributed under the terms of the Creative Commons Attribution License (http://creativecommons.org/licenses/by/4.0), which permits unrestricted use, distribution, and reproduction in any medium, provided the original work is properly credited. The Creative Commons Public Domain Dedication waiver (http://creativecommons.org/publicdomain/zero/1.0/) applies to the data made available in this article unless otherwise stated. 
femoral vein graft into the distal ends of the contralateral femoral artery and vein, and then the loop is embedded by specific matrixes within an isolation chamber, where an axial vascularization is generated [5]. By manipulating the matrix and the chamber that hold the loop, the model has been applied in various tissue engineering studies. Lokmic et al investigated the spontaneous microcirculatory development of the AV loop in a protected space within a polycarbonate chamber, suggesting that the model possessed enormous potential by manipulating the chamber structure to conduct the growth of the tissue to required directions [6]. The AV loop has also been applied for bone tissue engineering with porous solid matrices $[7,8]$. The model could also carry cells suspended in soft matrix and provide an in vivo culture platform thus possesses the potential to generate a target organoid eventually. Brown et al seeded islet cells with matrigel into the model and the cells survived 3 weeks after implantation [9]. In another study on muscle tissue engineering using the AV loop model, primary myoblasts were seeded and later individual myoblasts fused to form multinucleated myotubes [10].

The AV-loop model provides a highly vascular, isolated tool for in vivo tissue engineering as well as angiogenesis and anti - angiogenesis studies. The angiogenic property is driven by different forces. Mechanical forces play themselves an important role through shear stress in producing a subcritical ischemic area where angiogenesis and vasculogenesis must start. So angiogenesis and vasculogenesis can also be a physically (mechanically) induced phenomenon from effects of turbulences and shear stress [11].

The AV loop model is a protected space separated from the surrounding tissue, and therefore is also a hypoxic environment for the inner tissue and cells. Hence the AV loop implanted in the isolation chamber is also a hypoxic model [12-15]. Hypoxia Inducible Factor (HIF) is a transcriptional factor that is the master regulator of oxygen homeostasis and it also plays an essential role in angiogenesis [16-18]. HIF consists of $\alpha$ and $\beta$ subunits. HIF- $1 \alpha$ is one of the three isoforms of HIF- $\alpha$, which is most critical for hypoxic response [19]. There are over 100 angiogenic genes found up to date that are directly or indirectly regulated by HIF- $1 \alpha$, such as Vascular Endothelial Growth Factor-A (VEGF-A) [20] and Basic Fibroblast Growth Factor (bFGF) [21].

The HIF- $1 \alpha$ subunit is constantly expressed, but will be degraded rapidly under normoxic condition. The Hydroxylases, mainly the Prolyl hydroxylase (PHD), [22] are greatly involved in the degradation of HIF-1 $\alpha$. In well-oxygenated cells, the prolyl hydroxylation is catalyzed with the presence of Fe (II) and oxygen. Whereas in hypoxia when the PHD is blocked or inhibited due to lack of oxygen, HIF- $1 \alpha$ is stabilized and dimerizes with the $\beta$ subunit, binds to target genes, and leads to the downstream activations towards increase target gene transcription.

The endogenous HIF-1 $\alpha$ levels can be increased by the suppression of PHD activity, either by reducing the cellular oxygen level or by combining the Fe (II) competitively. Dimethyloxallyl Glycine (DMOG) is a cell permeable, competitive inhibitor of the PHDs [23]. DMOG is an analogue of 2-oxoglutarate, and in this way it inhibits not only the HIF prolyl but also asparaginyl hydroxylases. Beside that it is predicted to inhibit other members of 2oxoglutarate-dependent dioxygenases. DMOG has been proved to be able to stabilize HIF- $1 \alpha$ both in vitro and in vivo [24-27], which can be superior to adding limited kinds of growth factors [28] (Figure 1).

HIF- $1 \alpha$ could accumulate in the nuclei of the hypoxic cells and the protein can be detected by immunohistochemistry staining. In our previous study, the loop sealed in the isolation chamber was discovered to undergo hypoxia, characterized by HIF-1 $\alpha$ up-regulation [29]. The vascularization followed the increasing of HIF$1 \alpha$ temporally, while spatially it was positively correlated with the HIF- $1 \alpha$ level, as well (Data not shown). Thus, to prove the hypothesis, the PHD inhibitor DMOG was applied to stablize the HIF- $1 \alpha$, to see weather the increase of HIF-1 $\alpha$ would induce the increase of vascularization in the AV loop.

\section{Methods}

\section{Animal model preparation}

Syngenic male Lewis rats at $300 \mathrm{~g}$ (Charles River GmbH, Sulzfeld, Germany were used in the experiment. The rats were specific pathogen free (SPF), kept with optimized and standardized animal housing. Ethical rules have been followed during the whole research.

All surgeries were performed under magnification with the same microscope (OPMI Vario 700, Karl Zeiss, Jena, Germany) by the same micro surgeon. The rat was laid on the back on the warming plate at $37^{\circ} \mathrm{C}$ under anaesthesia with $2 \%$ Isoflurane inhalation (Figure 2a). The left femoral vessels were exposed by the incision on the middle of the thigh, with the vasa vasorum removed and branches coagulated. The $1.5 \mathrm{~cm}$ vein graft was harvested from the contralateral femoral vein in the same way and was interposed between the distal ends of the left femoral artery and vein (Figure 2b). 11-0 suture (Ethicon, Norderstedt, Germany) was used to inosculate the end-toend anastomosis. When the loop was accomplished, it was then placed in a cylindrical Teflon chamber, fixed by 4 stabs and embedded by $720 \mathrm{ul}$ fibrin gel made up of $4 \mathrm{IU} / \mathrm{ml}$ fibrinogen and $2 \mathrm{IU} / \mathrm{ml}$ thrombin (Tisseel $\mathrm{VH}$ S/D, Baxter Healthcare S.A., Wallisellen, Switzerland) (Figure 2c). The chamber was sealed by a Teflon lid with 6-0 suture (Ethicon) and fixed on the thigh with 3-0 


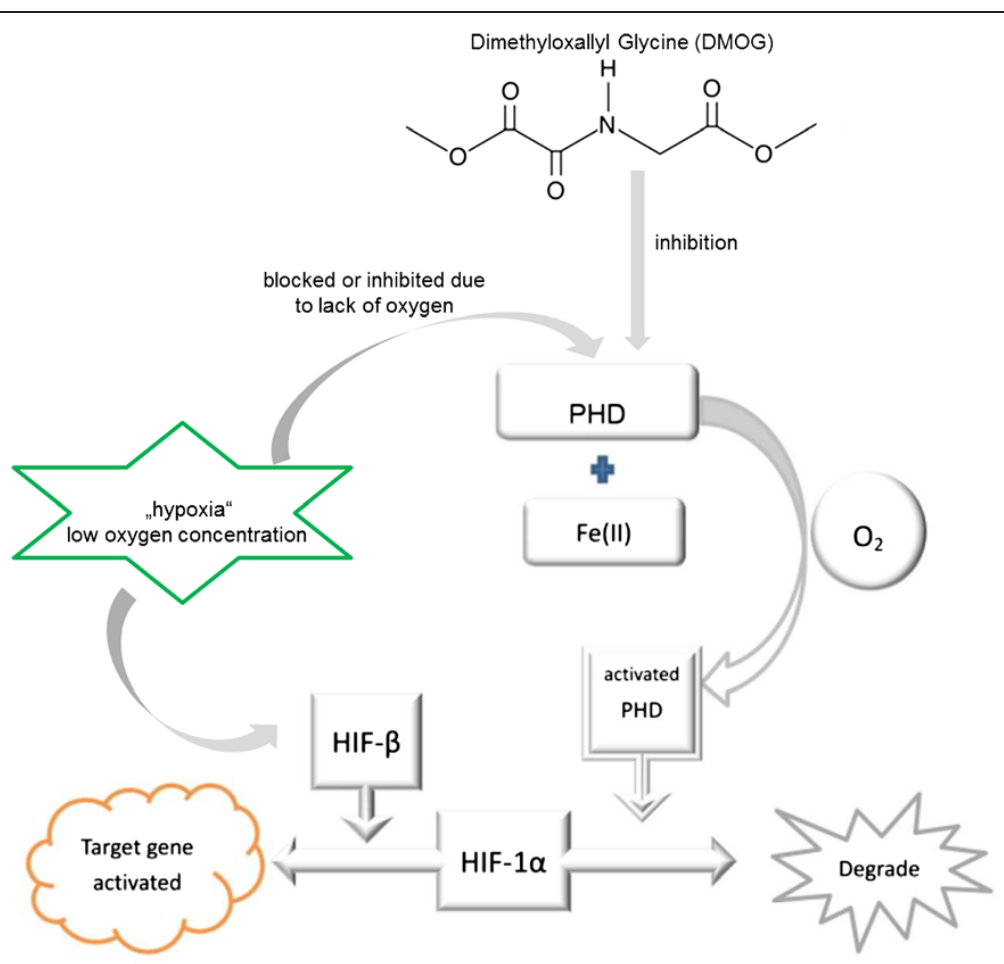

Figure 1 The Hydroxylase pathway of HIF-1a and DMOG structure. The Prolyl hydroxylase (PHD) is catalyzed with the presence of oxygen and Fe (II), then subsequently involved in the HIF protein degradation. Otherwise, HIF-1a is stabilized and dimerized with the HIF- $\beta$, and activates the target genes. DMOG structure (From SciFinder ${ }^{\circledast}$ ).
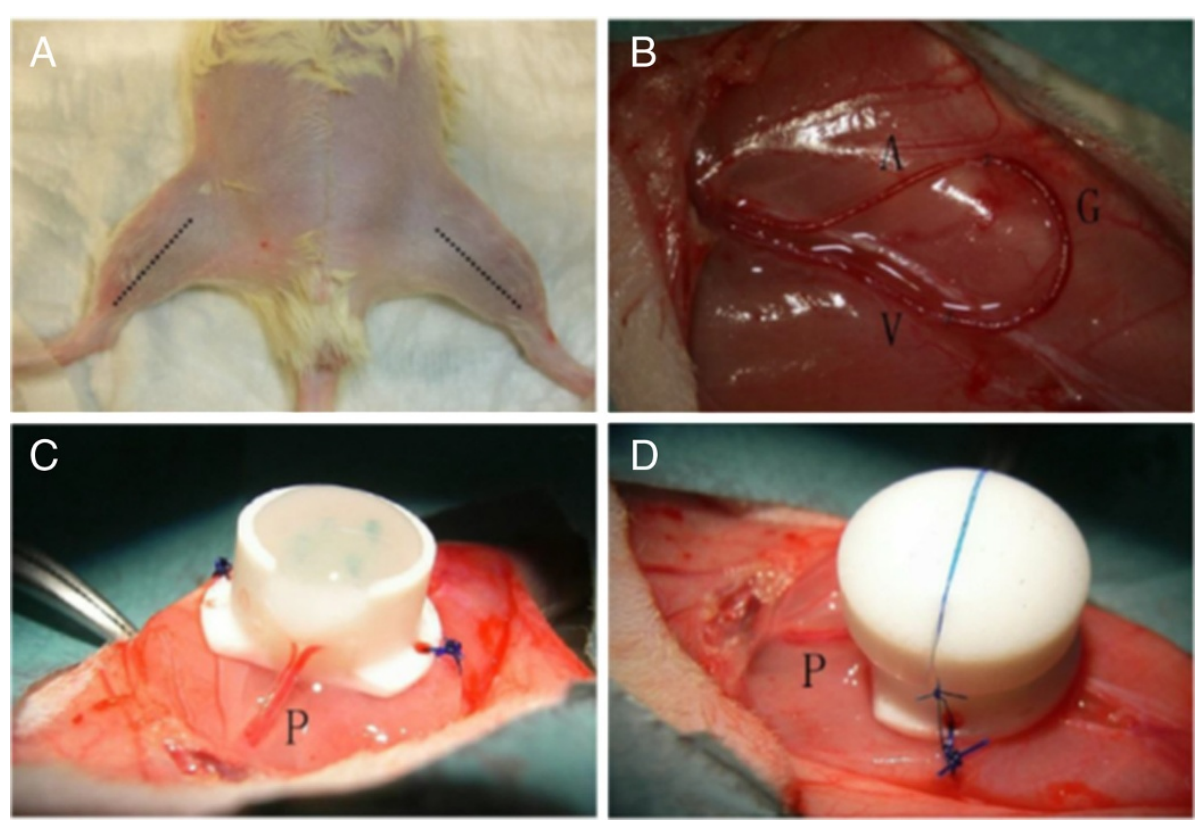

Figure 2 The surgical procedures of AV Loop preparation. A) Incisions on the thighs. B) The AV Loop: A=artery, $V=$ vein, $G=$ graft from the contralateral femoral vein. C) Loop fixed in the chamber, embedded by fibrin clot. D) The isolation chamber covered by the lid and fixed on the left thigh. $\mathrm{P}=$ pedicle. 
suture (Ethicon). (Figure 2d). After the skin closure, the rat was given 60 I.U. heparin subcutaneously and antibiotics (Veracin compositum) $0.2 \mathrm{ml}$ intramuscularly. The wound was covered by Aluminum spray.

\section{Group settings and drug administration}

The rats were randomly allocated into 3 groups:

1) control group $(n=6)$,

2) DMOG-1group ( $n=6)$ : DMOG $40 \mathrm{mg} / \mathrm{kg}$, i.p. at day 0 and day 2 ,

3) DMOG-2 group ( $n=6)$ : DMOG $15 \mathrm{mg} / \mathrm{kg}$, i.p. at day 8, day 10 and day 12.

DMOG (cayman, 71210) was freshly dissolved with saline before use. The animals underwent an observation period of 2 weeks. Upon the date for explantation, the distal $2 / 5$ of the specimens were frozen in liquid nitrogen, stored in $-70^{\circ} \mathrm{C}$ fridge before sent to further RNA isolation and qPCR analysis. The proximal $3 / 5$ of the specimens was fixed in 4\% PFA for routine histology analysis. Kidneys were also kept as organ control to see the DMOG remained systemically.

\section{Immunohistochemistry}

ROI

Transverse section across the central was picked, (Figure 3). In each slide, the ROI were taken in 4 directions from the central vessels.

The plane in the picture demonstrated the slide cut in the middle of the clot. As the blade cut across the specimen, the transverse section was harvested, which was marked with red board.

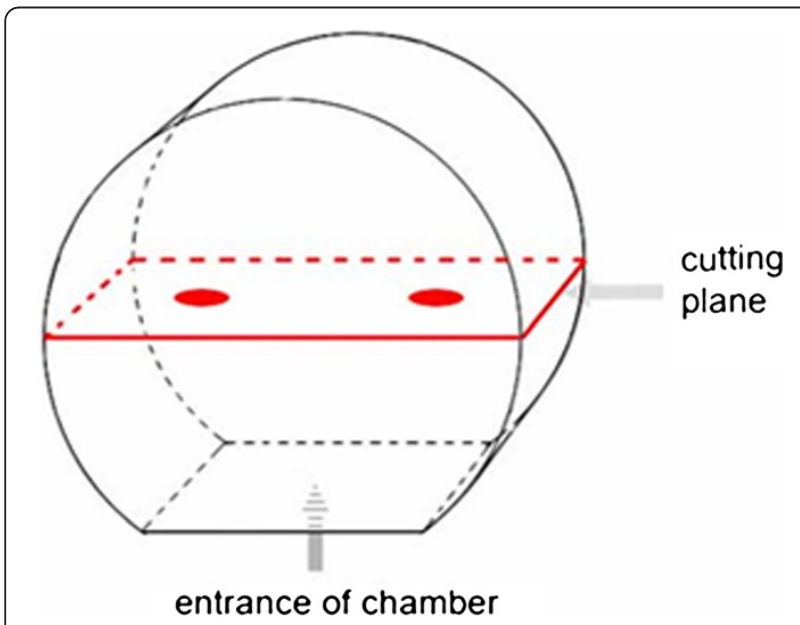

Figure 3 The cutting plane in the fibrin clot containing a loop. The plane in the picture demonstrated the slide cut in the middle of the clot. As the blade cut across the specimen, the transverse section was harvested, which was marked with red board.

\section{HIF-1a IHC}

The staining was performed with Dako Catalyzed Signal Amplification (CSA) system (K1500) based on "ABC method". After the $7 \mathrm{~min}$ cooking in pressure cooker at $121^{\circ} \mathrm{C}$ for antigen retrieval, The slides were successively blocked with Peroxidase Block for 10 min, Avidin Block (Vector Avidin/Biotin blocking Kit) for $20 \mathrm{~min}$, Biotin block(Vector Avidin/Biotin blocking Kit) for $20 \mathrm{~min}$ and Protein Block (CSA kit) for $30 \mathrm{~min}$. The slides were subsequently incubated with the primary antibody Polyclonal rabbit anti HIF-1 $\alpha$ (Cayman 10006421) in 1:50000 dilution in $2 \sim 8^{\circ} \mathrm{C}$ fridge overnight, and then the secondary antibody Biotinylated polyclonal Goat anti Rabbit (Dako E0432) in 1:2000 dilution in 2\% rat serum for $15 \mathrm{~min}$ in room temperature, succeeding the incubation of Strepavidin-Biotin Complex (SBC, from CSA kit, prepared 30 min before use), Amplification reagent (CSA kit) and Strepavidin-Peroxidase (CSA kit) for 15 min separately. In the end the slides were developed by DAB.

\section{Lectin IHC}

Cross sections were cut from the central part of the Loop and Lectin IHC was performed. The newly grown vessels in the granulation tissue in the AV loop were Lectin IHC positive, appeared in brown lining in lumens. After the pictures of each slide were taken by camera with the Leica application software, the area of cross section was measured by Leica application software. The absolute vessel number was counted manually and by dividing it to the cross section area, the vessel density was calculated as well.

The slides were cooked in pressure cooker for $1 \mathrm{~min}$ for antigen retrieval. Isolectin B4 Biotinylated antibody (Bandeiraea Simplicifolia Sigma L2140) was diluted to 1:250 with Tris buffer, incubated in $2 \sim 8^{\circ} \mathrm{C}$ fridge overnight, following the reaction with Streptavidin-peroxidase for $30 \mathrm{~min}$. The signal was developed by DAB for approximately $10 \mathrm{~min}$.

\section{Ki67 IHC}

After 1min cooking in high pressure cooker, the staining was performed with Polymer kit (ZytoChem Plus AP Polymer Kit), using the antibody Monoclonal rabbit anti Ki67 (Zytomed RBK 027) in 1:200 dilution, and developed by Fast red.

Generally, unless specifically stated, the slides were incubated horizontally at room temperature $\left(20^{\circ} \mathrm{C}\right)$. After the incubations there were three times of bath in Tristween buffer, only the rinse after the blocking applied Tris buffer without tween.

\section{Real-time Polymerase chain reaction (PCR)}

RNA was isolated with the RNeasy ${ }^{\oplus}$ Fibrous Tissue Midi kit (Qiagen, Hilden, Germany) according to manufacturer's 
instructions. cDNA was synthesized using $500 \mathrm{ng}$ total RNA with random hexamer priming and the RevertAid ${ }^{\mathrm{m}}$ First Strand cDNA Synthesis Kit (Thermo Scientific, Inc., Waltham, MA, USA). Real time PCR was performed in a CFX96 Touch $^{\text {sm }}$ Real-Time PCR Detection System and analyzed with the CFX Manager ${ }^{\mathrm{rm}}$ Software (Bio-Rad Laboratories, Inc., Hercules, CA, USA). The $20 \mu \mathrm{l}$ total reaction volume in each well of 96-well plate included: $10 \mu \mathrm{l}$ SsoAdvanced $^{\text {mi }}$ SYBR $^{\circ}$ Green Supermix, 0.6 $\mu$ l forward primer, $0.6 \mu \mathrm{l}$ reverse primer, $7.8 \mu \mathrm{l}$ nuclease-free water, and $1 \mu \mathrm{l}$ cDNA (25 ng). The amount of each transcript was normalized to GAPDH. The mRNA expression of the control loop served as control and was set as 1 . The calculation of the expression ratios was performed using the comparative Ct-method. Following is the list for the primers that were applied: Primer $\left(5^{\prime}-3^{\prime}\right)$ :

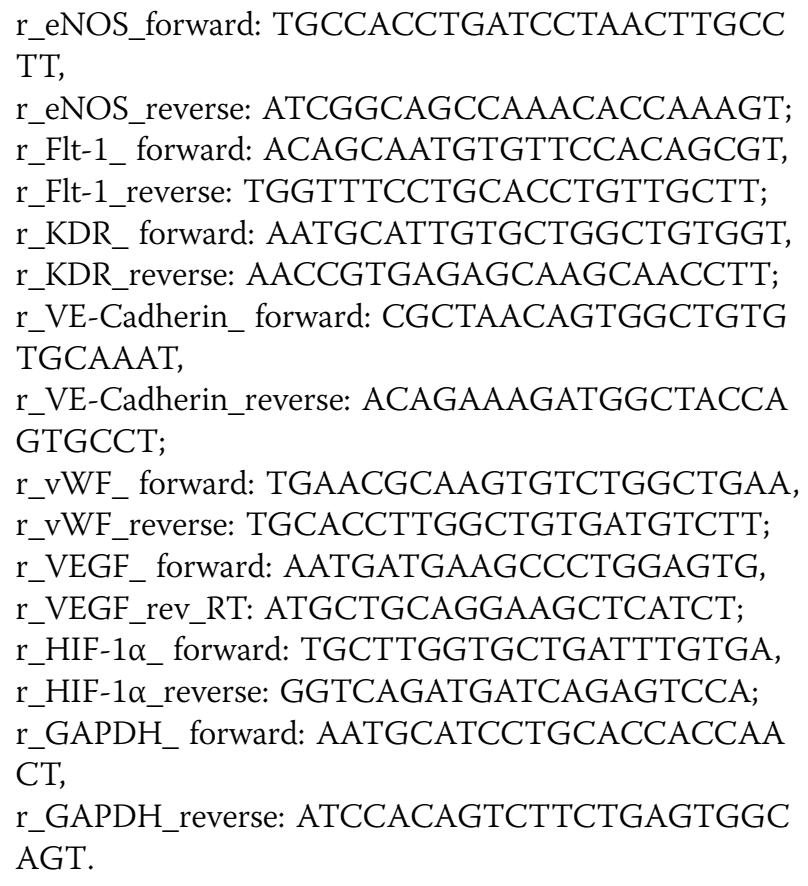

\section{Evaluation and statistics}

Pictures for the ROI were taken by the same microscope (Zeiss Carl Zeiss Meditec Vertriebsgesellschaft mbH, Oberkochen, Germany). The measures of the area of the clot were made by the software Leica Application (Leica Microsystems, Wetzlar, Germany). The counting of the vessels and cells in each ROI was made manually by blind tester. Statistical analysis was performed using Student's-Test and with SPSS. $\mathrm{P}<0.05$ was considered of statistical significance and labeled.

\section{Research involving human subjects}

There was no Research involving human subjects (including human material or human data) that is reported in the manuscript.
All experiments were approved by the animal care committee of the University of Erlangen and the Government of Mittelfranken, Germany (54-2532.1-28/09).

\section{Results: (whole section was reorganized)}

Systemic and local effects of DMOG: HIF-1a is positive in DMOG-2 group in kidneys and HIF-1a positive cells increased significantly in DMOG-2 group in the AV loop The effect of the systemic application of DMOG can only be shown in DMOG-2 group. As HIF- $1 \alpha$ accumulated in the nuclei in hypoxic cells, the positive signal appeared in intensive brown in IHC staining. In DMOG-1 group (DMOG given at day 0 and day 2 at $40 \mathrm{mg} / \mathrm{Kg}$ ) HIF- $1 \alpha$ IHC was negative at day 14 . However, in DMOG2 group (DMOG given at day 8,10 , and 12 at $15 \mathrm{mg} / \mathrm{Kg}$ ) a few HIF- $1 \alpha$ positive cells in the kidney can be observed (Figure $4 \mathrm{~A}, \mathrm{~B}, \mathrm{C}$ ).

Beside systemically effects of DMOG HIF- $1 \alpha$ positive cells increased significantly in DMOG-2 group in the AV loop (Figure 4D).

8 ROIs were taken in each slide, in 4 directions from the central artery and vein. In each picture, HIF- $1 \alpha$ positive cell number and total cell number were counted manually and the percentage of HIF- $1 \alpha$ cells was calculated. Comparing to the control group, the DMOG-2 group had 48\% HIF- $1 \alpha$ positive cells, which is significantly higher than the control group that had $10 \%$ HIF- $1 \alpha$ positive cells out of the total cell ingredients $\left({ }^{*} \mathrm{P}<0.05\right)$.

\section{DMOG effects on the vascularisation in the AV loop: higher vessel density and smaller cross section area in DMOG-2 group}

Comparing to the other groups, the DMOG-2 group possessed a significantly smaller cross section area. $\left(17.8 \times 10^{6} \mu \mathrm{m}^{2}, 14.4 \times 10^{6} \mu \mathrm{m}^{2}\right.$ versus $9.4 \times 10^{6} \mu \mathrm{m}^{2}, *, \# \mathrm{p}<$ 0.05). The cross section area of the control group was bigger than the experimental groups (Figure 5A).

As for the absolute vessel number, no significance was found between the control group (212/cross section), the DMOG-1 group (229/cross section) and DMOG-2 group (272/cross section), but a trend could be observed that the DMOG-1 group tend to have more vessels than the control group, whereas the DMOG-2 group possessed the most vessels (Figure 5B).

The DMOG-2 group significantly possessed a higher vessel density $\left(3.0 \times 10^{-5} / \mu \mathrm{m}^{2}\right)$ than the control group $\left(1.2 \times 10^{-5} / \mu^{2}, " \mathrm{p}<0.05\right)$ and the DMOG-1 group $\left(1.6 \times 10^{-5} / \mu \mathrm{m}^{2}, \# \mathrm{p}<0.05\right)$ (Figure $5 \mathrm{c}$ ).

DMOG effects on cell proliferation in the AV loop: Ki67 IHC: more positive cells in DMOG-2 group

Ki67 is a nucleus protein that is associated with cell proliferation activity [30]. In Ki67 IHC staining, positive cells were red in nuclei whereas the negative cells counter 


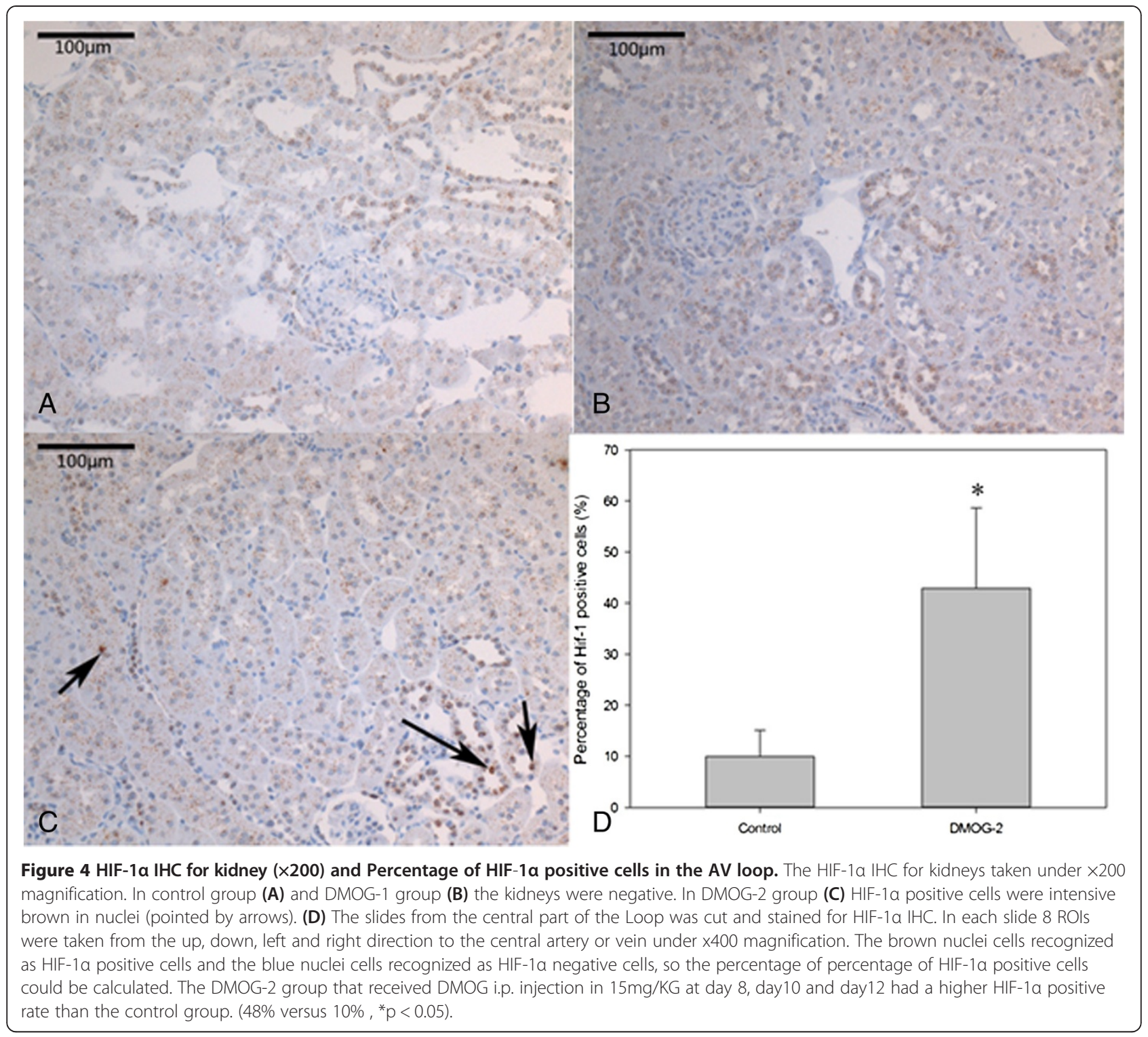

stained with haematoxylin were with blue nuclei. More positive cells were observed in DMOG-2 group all over the slide, (Figure 6: control group artery and vein/DMOG-1 group artery and vein/DMOG-2 group artery and vein) indicating that DMOG may not result in the depression of proliferation of cells in vivo.

\section{DMOG effects on angiogenic gene expression levels in the AV loop: real time PCR: mRNA of HIF-1 $\alpha$ and its angiogenic target genes increased}

The distal 2/5 part of the fibrin clot containing the AV loop as the vascular outgrowth from the axial loop was sent to RNA isolation, the mRNA of HIF- $1 \alpha$ as well as its target genes that were considered to be related to angiogenesis, including: eNOs, VE cadherin, VEGF, Flt-1, and $v W F$ were quantified by real time PCR [31]. The graph below demonstrates the mRNA levels of DMOG2 group compared to the control group in folds. The HIF- $1 \alpha$ elevated more than 10 folds in the DMOG-2 group. Correspondingly, its target genes elevated to different extends. In particular the vWF raised significantly $(* \mathrm{P}<0.05)$ (Figure 7).

\section{Discussion}

The AV loop model is a promising vascularization model in the in vivo tissue engineering studies. The loop underwent hypoxia in the isolation chamber and the hypoxia pattern may have some relationship with the vascularization process according to our previous study which investigated the hypoxia pattern in the AV Loop spatially and temporally. The present study intends to prove, that the PHD inhibitor DMOG could be able to stimulate the vessel 

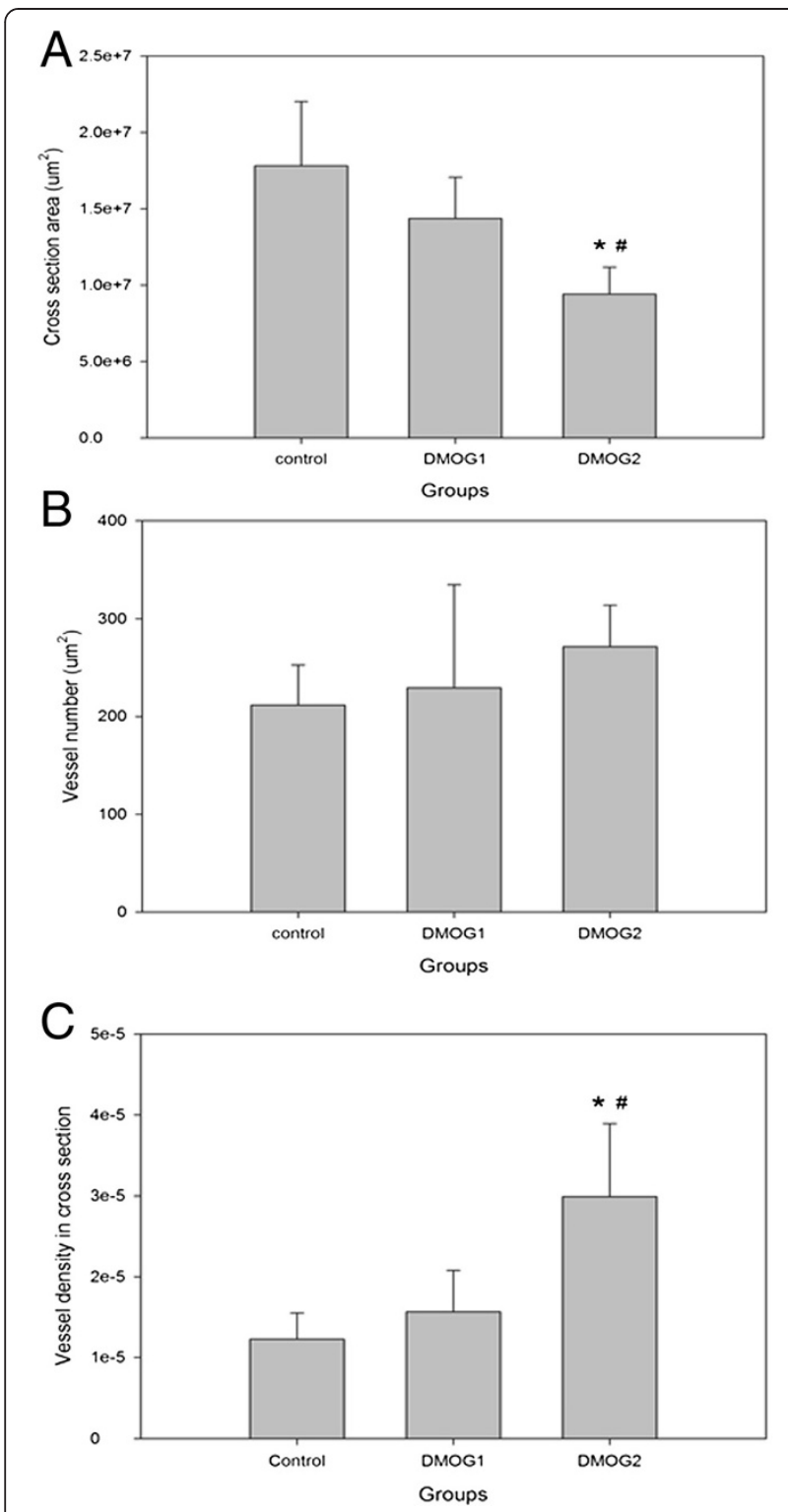

Figure 5 Cross section area/absolute vessel number/vessel density in cross section. Cross section was cut from the central part of the Loop and Lectin IHC was performed. The cross section area was measured by Leica application software $\mathbf{A})$. Cross section area $\left(\mu^{2}\right)$ : the DMOG-1 group $\left(14.4 \times 10^{6} \mu \mathrm{m}^{2}\right)$ tended to be smaller than the control group $\left(17.8 \times 10^{6} \mathrm{\mu m}^{2}\right)$ and bigger than the DMOG-2 group $\left(9.4 \times 10^{6} \mu \mathrm{m}^{2}\right)$, but no statistic significance was found. The DMOG-2 group shrinks significantly comparing to the other groups. B). absolute vessel number: no significance was found between the control group (212/cross section), the DMOG-1 group (229/cross section) and DMOG-2 group (272/ cross section), but a trend could be observed that the DMOG-1 group tend to have more vessels than the control group, whereas the DMOG-2 group possessed the most vessels. C). vessel density in cross section: The DMOG-2 group significantly possessed a higher vessel density $\left(3.0 \times 10^{-5} / \mathrm{\mu m}^{2}\right)$ than the control group $\left(1.2 \times 10^{-5} / \mu m^{2},{ }^{*} p<0.05\right)$ and the DMOG-1 group $\left(1.6 \times 10^{-5} / \mu m^{2} \# p<0.05\right)$. outgrowth from the axial AV loop when it stabilizes HIF, hence to prove that HIF- $1 \alpha$ is the stimulus for vascularization in the AV loop model. Beside effects of hypoxia angiogenesis and vasculogenesis can also be a mechanically induced phenomenon from effects of turbulences and shear stress [11]. Mechanical forces themselves can play an important role through shear stress in producing a subcritical ischemic area where angiogenesis and vasculogenesis must start.

\section{PHD inhibitor up-regulate HIF-a}

The PHD inhibitor has been used as HIF- $\alpha$ stabilizer to suppress the HIF- $\alpha$ degradation by hydroxylase pathway in studies that needs to up-regulate HIF- $\alpha$. Warnecke et al had successfully induced HIF- $\alpha$ expression in vivo and in vitro. The renal HIF- $\alpha$ was increased and by repeated local injection into the sponge that was embedded subcutaneously, angiogenesis was induced [32]. Song et al had dissolved DMOG in PBS and delivered DMOG to rats in $15 \mathrm{mg} / \mathrm{kg} /$ day via an osmotic pump and had a renoprotection and HIF- $\alpha$ induction accompanied by a reduction of oxidative stress, inflammation and fibrosis [25]. Nagel et al discovered that DMOG given to rats at $0 \mathrm{~h}, 8 \mathrm{~h}$ and $16 \mathrm{~h}$ postoperatively in $40 \mathrm{mg} / \mathrm{kg}$ by i.p. injection helped to improve the behavior after brain ischemia [24]. This study proved that in the early stage (upon 2 weeks of implantation) vascularization process in the AV loop could be accelerated by the PHD inhibitor DMOG, with smaller dosages maintained in the system, accompanied with the HIF- $1 \alpha$ protein increase.

\section{Kinetics of DMOG in rat}

DMOG given at lower dosage constantly after one week tend to have better effect than the group given at larger dosage in the early stage in this model. Till now the kinetics in the rat is still unclear, either from the manufacturer or from the literature. What we do know is that according to the molecular structure provided by the manufacturer (Figure 1), this chemical possesses strong polarity, which means it is highly soluble in water. It may not be active in solution for over one week, and it chelates with $\mathrm{Fe}$ (II) rapidly and strongly.

Since the fibrin matrix is porous [33] and proved to be able to function as slow release system for growth factors such as VEGF and bFGF [34], it may be also interesting that whether DMOG can be loaded in the matrix upon the implantation of the AV Loop, and be released later on. In the preliminary experiment the DMOG was dissolved in fibrin in different dilution in Teflon chambers and imbedded in as up-side-down manner as described before [35] and the dorsal muscle that attach to the fibrin clot were examined at day 7 and day 1 , and there was no sign of HIF- $1 \alpha$ up-regulation or increase of vascularization (data not shown). 

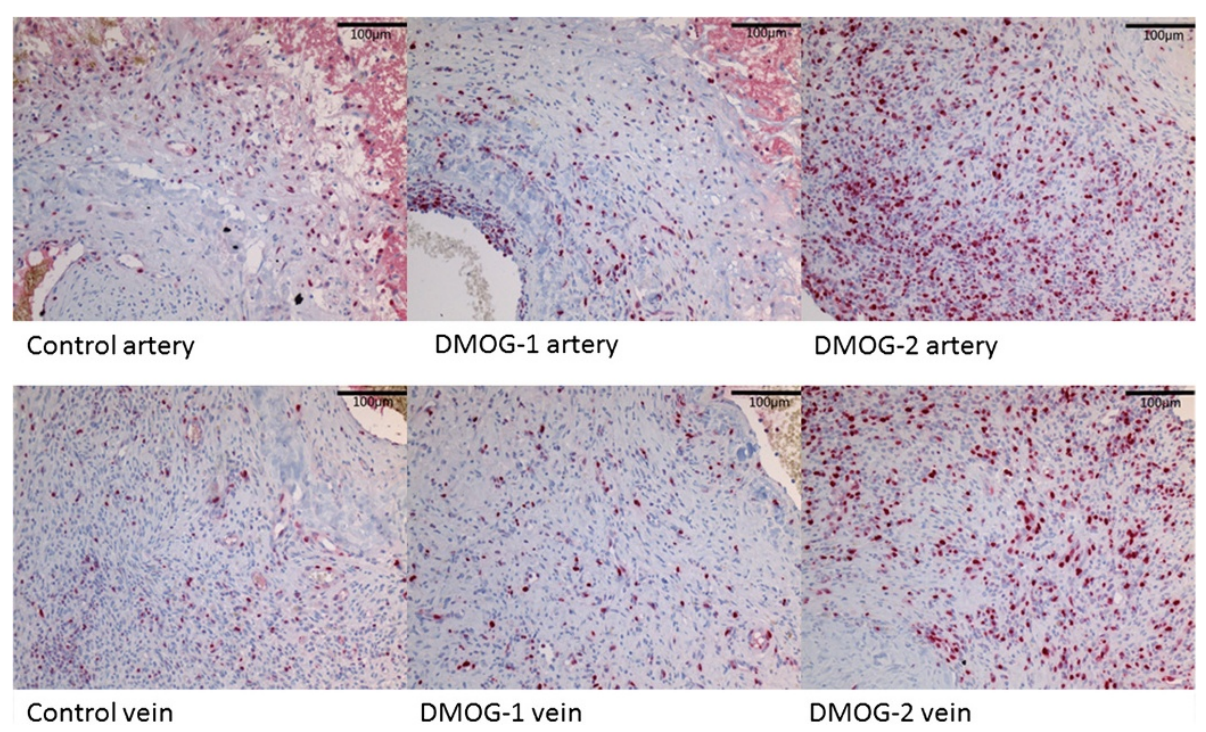

Figure 6 Ki67 Immunohistochemistry staining. The slides were picked from the central transversal section, and stained for Ki67 which was a proliferation indicator located in the nuclei. Positive cells were rosa red in nuclei while the negative cells were blue. Pictures from the central artery and vein were taken for each group. A few positive cells could be found in the control group and DMOG-1 group, and tremendous positive cells could be found in the DMOG-2 group, indicating that in the DMOG-2 group the proliferation of the cells were more active.

Subsequently the DMOG was applied systemically by i.p. injection. As the Kidneys were sensitive to DMOG, [32] [25] it was utilized as organ control to indicate the systemic level of drug. In this study, kidneys from both of the control group and the DMOG-1 group were negative whereas in DMOG-2 group positive cells were observed, indicating that DMOG would be degraded or expelled from the system within days, and won't maintain for more than a week. From this we can infer that administrate the drug continuously or repeatedly, rather than in a shock therapy would maintain this drug in system as long as possible. The time points of applying the drug are also important in this study. According to the previous investigation for the pattern of vascularization of the AV Loop, there are few cells exudate from the central vessels at the first week upon the loop implantation. The granulation tissue which contains newly grown vessels generate rapidly in the second week when

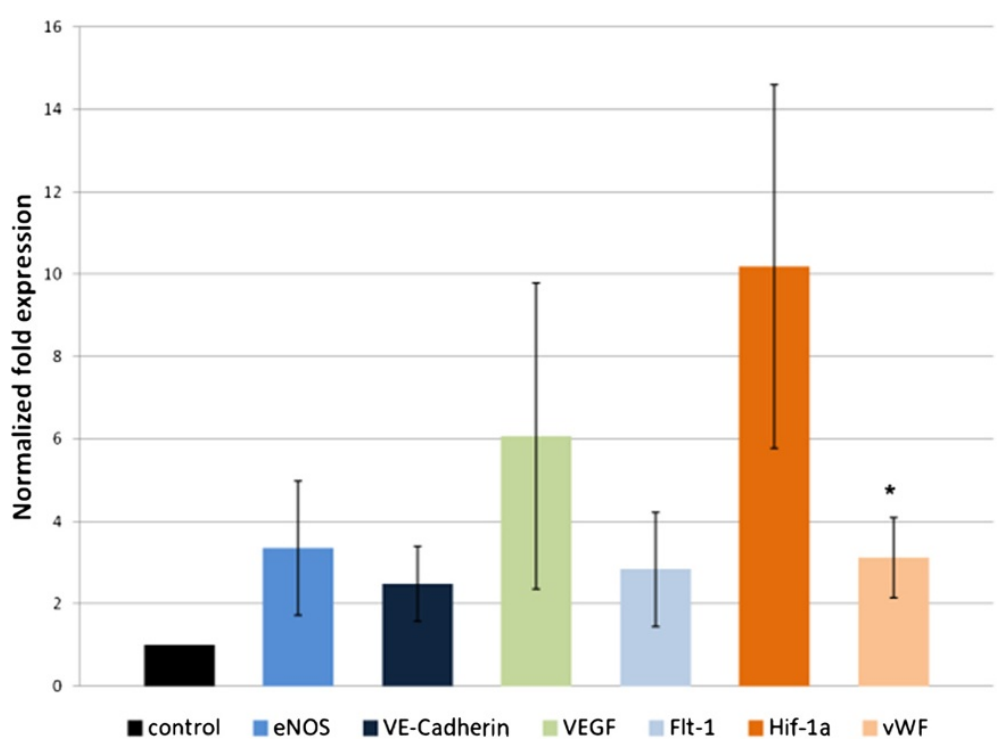

Figure 7 mRNA normalized fold expression. The DMOG-2 group was given DMOG in 15 mg/Kg by i.p. injection at day 8 , day 10 and day 12 $(n=6)$. The specimens were explanted at day 14 and the distal 2/5 part of the clots were sent to mRNA analysis. Data given are mean mRNA levels of HIF-1a, eNOs, VE cadherin, VEGF, Flt-1, and VWF expressed as fold increase above control group ( $\left.{ }^{*} \mathrm{P}<0.05\right)$. 
tremendous cells could be observed in the fibrin clot [5]. So in the second week there are much more cells that can be induced to accumulate more HIF-1 $\alpha$, and hence more tremendous outcome in vessel outgrowth.

\section{Further effects of PHD}

As the PHD family inhibit HIF- $\alpha$ via competitively chelating the $\mathrm{Fe}$ (II), which is an essential co-factor for many enzymes [36], they may have effects in diverse physiological activities which those enzymes are involved in. In Song's study the DMOG treatment decreased macrophage infiltration and reduced fibrosis [27]. However, in our study, the Ki67 IHC which indicates the cell proliferation [30] demonstrates that DMOG does not inhibit the proliferation but on contrary activate the mitosis of the infiltrating cells in the fibrin matrix.

In this study, the HIF- $1 \alpha$ was up-regulated at protein level, but also at the mRNA level, indicating that DMOG may be also involved in the HIF- $\alpha$ up-regulation transcriptionally, aside from stabilizing the protein from hydroxylation.

\section{Perspectives}

In order to generate a three dimensional construct, it seems necessary that cultured cells are seeded into a scaffold that can mimic the structure and the environment for cell growth, and allow the exchange of oxygen, nutrient and the waste. As an in vivo animal model for tissue engineering, specific cells can be seeded in the chamber to generate corresponding tissue or organ $[9,10]$. As an in vivo model, the knowledge about the vascularization pattern corresponding to hypoxia and HIF- $1 \alpha$ expression can help modulate the vascular growth. Since bFGF and VEGF immobilized in the fibrin matrix can improve the vascularization of AV loop [34] and it may be a superior choice to manipulate the neo vessel outgrowth by upregulation their transcription factor HIF-1 $\alpha$ [28], the PHD inhibitor is a good option.

\section{Summary}

The PHD inhibitor DMOG was utilized as HIF-1 $\alpha$ stablizer in the study. DMOG was applied in two ways: at early stage (day 0, day3) of the loop in larger dosage $(40 \mathrm{mg} / \mathrm{kg})$, or at later stage (day 8 , day 10 , day 12 ) in smaller dosage $(15 \mathrm{mg} / \mathrm{kg})$, namely DMOG-1 group and DMOG-2 group. Upon the explantation at day 14, DMOG was only still functioning in the system in DMOG-2 group. This was evidence by the HIF- $1 \alpha$ IHC for the kidneys that were sensitive to the PHDs stimulation that HIF- $1 \alpha$ positive renal cells were only observed in DMOG-2 group.

Also, in DMOG-2 group the HIF- $1 \alpha$ positive cell percentage raised significantly and mRNA was over 10 folds over the control group, indicated that HIF- $1 \alpha$ was upregulated at protein level and mRNA level. The mRNA of its angiogenic target genes such as eNOs, VE cadherin, VEGF, Flt-1, and vWF were up-regulated as well. The cross section area decreased and the vessel denstiy increased in DMOG-2 group, hint that the fibrin clot was degraded faster and the vascularization more active.

Addistional evidence was the Ki67 IHC which could demonstrate the activuty of cell proliferation. In DMOG-2 group there were tremendous Ki67 positive cells comparing to the control group and the DMOG-1 group.

\section{Conclusions}

In summary the process of the vascularization can be stimulated by DMOG in the AV Loop model. DMOG given at lower dosage constantly after one week tends to have better effect than the group given at larger dosage in the early stage in this model, and promotes the cell proliferation.

\section{Competing interests}

The author's declare that they have no competing interests.

\section{Authors' contributions}

YQ performed the experiments, took photographs from histology slides, prepared and wrote first draft of manuscript, $O B$ and $A M B$ helped to conceive the study and participated in the experimental design and coordination, $A B$ and $A M B$ helped to perform and supervise the experiments and contributed to the study design and results analyses. JS, AMB, APB, AA, MS, UK corrected draft and manuscript. REH participated in design and coordination of the study, corrected draft and prepared final manuscript. All authors have been involved in drafting the manuscript or revising it critically for important intellectual content and all authors read and approved the final manuscript.

\section{Acknowledgement}

The study was founded by the Else Kröner-Fresenius Stiftung. The authors want to thank the China Scholarship council for the financial support for her doctoral study of Y.Q. in the University of Erlangen, and the ELAN Fund of the FAU, and the Xue Hong and Hanns Georg Geis Stiftung for their continuous support in Tissue Engienering and Regenerative Medicine Research. We acknowledge support by Deutsche Forschungsgemeinschaft and Friedrich-Alexander-Universität Erlangen-Nürnberg (FAU) within the funding programme Open Access Publishing

\section{Author details}

'Department of Plastic and Hand Surgery, University Hospital of Erlangen, Friedrich Alexander University, Erlangen Nuernberg, (FAU), Germany. ${ }^{2}$ Department of Plastic Surgery, Union Hospital, Huazhong University of Science and Technology, Wuhan, China. ${ }^{3}$ Department of Hand, Plastic and Reconstructive Surgery, Burn Care Unit, BG-Trauma Centre Ludwigshafen, University of Heidelberg, Ludwigshafen, Germany.

Received: 8 February 2014 Accepted: 16 December 2014 Published online: 28 December 2014

\section{References}

1. Novosel EC, Kleinhans C, Kluger PJ: Vascularization is the key challenge in tissue engineering. Adv Drug Deliv Rev 2011, 63(4-5):300-311.

2. Jain RK, Au P, Tam J, Duda DG, Fukumura D: Engineering vascularized tissue. Nat Biotechnol 2005, 23(7):821-823.

3. Bleiziffer $\mathrm{O}$, Hammon M, Arkudas A, Taeger CD, Beier JP, Amann K, Naschberger E, Stürzl M, Horch RE, Kneser U: Guanylate-binding protein 1 expression from embryonal endothelial progenitor cells reduces blood vessel density and cellular apoptosis in an axially vascularised tissue-engineered construct. BMC Biotechnol 2012, 12:94.

4. Erol OO, Spira M: New capillary bed formation with a surgically constructed arteriovenous fistula. Surg Forum 1979, 30:530-531. 
5. Polykandriotis E, Arkudas A, Horch RE, Stürzl M, Kneser U: Autonomously vascularized cellular constructs in tissue engineering: opening a new perspective for biomedical science. J Cell Mol Med 2007, 11:6-20.

6. Lokmic Z, Stillaert F, Morrison WA, Thompson EW, Mitchell GM: An arteriovenous loop in a protected space generates a permanent, highly vascular, tissue-engineered construct. FASEB J 2007, 21(2):511-522.

7. Kneser U, Polykandriotis E, Ohnolz J, Heidner K, Grabinger L, Euler S, Amann KU, Hess A, Brune K, Greil P, Stürzl M, Horch RE: Engineering of vascularized transplantable bone tissues: induction of axial vascularization in an osteoconductive matrix using an arteriovenous loop. Tissue Eng 2006, 12(7):1721-1731.

8. Beier JP, Hess A, Loew J, Heinrich J, Boos AM, Arkudas A, Polykandriotis E, Bleiziffer O, Horch RE, Kneser U: De novo generation of an axially vascularized processed bovine cancellous-bone substitute in the sheep arteriovenous-loop model. Eur Surg Res 2011, 46(3):148-155.

9. Brown DL, Meagher PJ, Knight KR, Keramidaris E, Romeo-Meeuw R, Penington AJ, Morrison WA: Survival and function of transplanted islet cells on an in vivo, vascularized tissue engineering platform in the rat: A pilot study. Cell Transplant 2006, 15(4):319-324.

10. Borschel GH, Dow DE, Dennis RG, Brown DL: Tissue-engineered axially vascularized contractile skeletal muscle. Plast Reconstr Surg 2006 117(7):2235-2242.

11. Manasseri B, Cuccia G, Moimas S, D'Alcontres FS, Polito F, Bitto A, Altavilla D, Squadrito F, Geuna S, Pattarini L, Zentilin L, Collesi C, Puligadda U, Giacca M, Colonna MR: Microsurgical arterovenous loops and biological templates: a novel in vivo chamber for tissue engineering. Microsurgery 2007 27(7):623-629.

12. Horch RE, Boos AM, Quan $Y$, Bleiziffer O, Detsch R, Boccaccini AR, Alexiou C, Sun J, Beier JP, Arkudas A: Cancer research by means of tissue engineering - is there a rationale? J Cell Mol Med 2013, 17(10):1197-1206.

13. Rath SN, Strobel LA, Arkudas A, Beier JP, Maier AK, Greil P, Horch RE, Kneser U: Osteoinduction and survival of osteoblasts and bone-marrow stromal cells in 3D biphasic calcium phosphate scaffolds under static and dynamic culture conditions. J Cell Mol Med 2012, 16(10):2350-2361.

14. Horch RE, Kneser U, Polykandriotis E, Schmidt VJ, Sun J, Arkudas A: Tissue engineering and regenerative medicine -where do we stand? I Cell Mol Med 2012, 16(6):1157-1165.

15. Polykandriotis E, Schmidt VJ, Kneser U, Jianming S, Boccaccini AR, Horch RE: [Bioreactors in regenerative medicine-from a technical device to a reconstructive alternative?]. Handchir Mikrochir Plast Chi 2012, 44(4):198-203.

16. Pugh CW, Ratcliffe PJ: Regulation of angiogenesis by hypoxia: role of the HIF system. Nat Med 2003, 9(6):677-684.

17. Leffler M, Derrick KL, McNulty A, Malsiner C, Dragu A, Horch RE: Changes of anabolic processes at the cellular and molecular level in chronic wounds under topical negative pressure can be revealed by transcriptome analysis. J Cell Mol Med 2011, 15(7):1564-1571.

18. Malsiner CC, Schmitz M, Horch RE, Keller AK, Leffler M: Vessel transformation in chronic wounds under topical negative pressure therapy: an immunohistochemical analysis. Int Wound J 2013. Sep 13. doi:10.1111/iwj.12143. [Epub ahead of print].

19. Gu YZ, Hogenesch JB, Bradfield CA: The PAS superfamily: sensors of environmental and developmental signals. Annu Rev Pharmacol Toxicol 2000, 40:519-561.

20. Forsythe JA, Jiang BH, lyer NV, Agani F, Leung SW, Koos RD, Semenza GL: Activation of vascular endothelial growth factor gene transcription by hypoxia-inducible factor 1. Mol Cell Biol 1996, 16(9):4604-4613.

21. Calvani M, Rapisarda A, Uranchimeg B, Shoemaker RH, Melillo G: Hypoxic induction of an HIF-1alpha-dependent bFGF autocrine loop drives angiogenesis in human endothelial cells. Blood 2006, 107(7):2705-2712

22. Weidemann A, Johnson RS: Biology of HIF-1alpha. Cell Death Differ 2008, 15(4):621-627.

23. Bruick RK, McKnight SL: A conserved family of prolyl-4-hydroxylases that modify HIF. Science 2001, 294(5545):1337-1340.

24. Nagel S, Papadakis M,Chen R,Hoyte LC,Brooks KJ, Gallichan D, Sibson NR, Pugh C, Buchan AM: Neuroprotection by dimethyloxalylglycine following permanent and transient focal cerebral ischemia in rats. J Cereb Blood Flow Metab. 31(1):132-143.

25. Gelse K, Pfander D, Obier S, Knaup KX, Wiesener M, Hennig FF, Swoboda B: Role of hypoxia-inducible factor 1 alpha in the integrity of articular cartilage in murine knee joints. Arthritis Res Ther 2008, 10:R111.
26. Lim CS, Qiao X, Reslan OM, Xia Y, Raffetto JD, Paleolog E, Davies AH, Khalil RA: Prolonged mechanical stretch is associated with upregulation of hypoxia-inducible factors and reduced contraction in rat inferior vena cava. J Vasc Surg 2011, 53(3):764-773.

27. Song YR, You SJ, Lee YM, Chin HJ, Chae DW, Oh YK, Joo KW, Han JS, Na KY: Activation of hypoxia-inducible factor attenuates renal injury in rat remnant kidney. Nephrol Dial Transplant 2010, 25(1):77-85.

28. Pajusola K, Künnapuu J, Vuorikoski S, Soronen J, André H, Pereira T, Korpisalo P, Ylä-Herttuala S, Poellinger L, Alitalo K: Stabilized HIF-1alpha is superior to VEGF for angiogenesis in skeletal muscle via adeno-associated virus gene transfer. FASEB J 2005, 19(10):1365-1367.

29. Dragu A, Kleinmann JA, Taeger CD, Birkholz T, Schmidt J, Geppert Cl, Präbst K, Unglaub F, Münch F, Weyand M, Kneser U, Horch RE: Immunohistochemical evaluation after ex vivo perfusion of rectus abdominis muscle flaps in a porcine model. Plast Reconstr Surg 2012 130(2):265e-273e.

30. Scholzen T, Gerdes J: The Ki- 67 protein: from the known and the unknown. J Cell Physiol 2000, 182(3):311-322.

31. Fong $\mathrm{GH}$ : Mechanisms of adaptive angiogenesis to tissue hypoxia. Angiogenesis 2008, 11(2):121-140.

32. Warnecke C, Griethe W, Weidemann A, Jürgensen JS, Willam C, Bachmann S, Ivashchenko Y, Wagner I, Frei U, Wiesener M, Eckardt KU: Activation of the hypoxia-inducible factor-pathway and stimulation of angiogenesis by application of prolyl hydroxylase inhibitors. FASEB J 2003, 17(9):1186-1188.

33. Breen $A, O$ B Brien T, Pandit A: Fibrin as a delivery system for therapeutic drugs and biomolecules. Tissue Eng Part B Rev 2009, 15(2):201-214.

34. Arkudas A, Tjiawi J, Bleiziffer $O$, Grabinger L, Polykandriotis E, Beier JP, Stürzl M, Horch RE, Kneser U: Fibrin gel-immobilized VEGF and bFGF efficiently stimulate angiogenesis in the AV loop model. Mol Med 2007, 13(9-10):480-487.

35. Bleiziffer O, Hammon M, Naschberger E, Lipnik K, Arkudas A, Rath S, Pryymachuk G, Beier JP, Stürzl M, Horch RE, Kneser U: Endothelial Progenitor Cells contribute to formation of capillaries and alter fibrocascular tissue after subcutaneous implantation in a fibrin matrix. J Cell Mol Med 2010, 15(11):2452-2461.

36. Hentze MW, Muckenthaler MU, Andrews NC: Balancing acts: molecular control of mammalian iron metabolism. Cell 2004, 117(3):285-297.

\section{Submit your next manuscript to BioMed Central and take full advantage of:}

- Convenient online submission

- Thorough peer review

- No space constraints or color figure charges

- Immediate publication on acceptance

- Inclusion in PubMed, CAS, Scopus and Google Scholar

- Research which is freely available for redistribution 